\title{
Understanding the Different Educational and Teaching Systems at Schools in Palestine
}

\author{
Shadi Emad. A. Alhaleh \\ Accounting and Finance Department, Faculty of Business Admnistration \\ Hebron University, Palestine \\ shadial2050@yahoo.com
}

\begin{abstract}
Palestinian education is one of best and strongest one in the Arab world, so, in this introduction will I explain about education methods in Palestine, so education is one of the most important thing in the country and that's in order to improve and develop a lot of different sectors in the country. But in Palestine the situation is a little bit different from other countries, because in Palestine, to get education services you should have a desire to create new educational methods that will lead to improve the quality of different fields of science at Palestinian educational institutions, so at schools, Palestinians teachers use technological educational methods in order to give better understanding how to learn and how to create ideas and how to think out of box. It is not about studying school books only and keeping it's information in our brains to be ready for the exams. In spite of the harsh political and economic circumstances that the Palestinian people are still fighting to get better education and to make Palestine the best place to get knowledge about different science fields. So, Palestinian people are so interested to send their daughters and sons to schools and universities to get better education and no matter how expensive is it, their parents dedicate their days and nights for their families in order to make them getting a lot of academic certifactes and experiences to improve the quality of education in Palestine. Finally, Palestinian people are trying to update new systems to be adopted at the educational organizations in order to make good quick changes in the system and to get a lot of benefits in return, no matter what the challenges they will face to control new educational systems at educational institutions.
\end{abstract}

Keywords: education system, teaching method, school definition and critical thinking

\section{INTRODUCTION}

What constitutes a good education is always contentious. In Palestine the debate about education began many years ago, but it is only recently that the analysis has become truly critical, focusing on the deep structures of learning and schooling. The available data in the Occupied Palestinian Territories indicate that both the curriculum content and modes of assessment in formal education do not respond adequately to the various challenges and demands of the political and socioeconomic conditions within this colonial context.

Students in schools, colleges and universities are taught to become passive recipients of prepackaged knowledge as a result of an outdated pedagogy that is associated with power structures and patriarchal elites. The teaching methodologies in Palestine fail to enhance critical thinking and the capacity to apply logic amongst the students from variable age categories. Facts are packaged, and are to be taken as absolute. Cultural and social taboos are strengthened while gender and class divisions are widened. It is inevitable that this has a major impact on the goals and mechanisms of the Palestinian national struggle towards liberation, self-determination and genuine sovereignty.

Moreover, it has harmful consequences for social and cultural development. However, the goals of education must be wider than that and it must be recognized that they can also be realised beyond the school doors. The various progressive social actors have an important, if not a determining, role towards developing approaches, philosophies and tools towards an effective emancipatory education that set minds free, accelerate creativity and open new perspectives and horizons for genuine human liberation (Frost, 2013).

Education is about hoe to get something new which is helpful and useful to solve wrong things in the society, during adopting new educational systems that will lead to eradicate all problems in the education process and a lot of benefits will be generated in order to deal with any upcoming future problems. So, Palestinian communities are so interested to establish many scientific institutions to develop the country and to change the bad indicators of their local economic, in this case Palestinian philosophy about education is so clear and the structural procedures, obligations, plans, educational policies and legal instructions are so pure to run the process of strong education in all different fields of science in the area. Regardless of poverty, unemployment and economic recession, in addition to poor financial budgets to support the process of teaching, Palestinians people are still fighting to achieve their goal in life to make Palestine one of the greatest country to get knowledge and experiences in all science fields.

Teaching process in Palestine alwayes faces unpredictable challenges such as obstacles, prevention and deprivation of getting the right of education and these obstacles created by occupation forces on all different parts of the area, sometime it is not easy to cross the street to go to schools and that's because of a lot of restrictions and limitations had set by occupation forces in Palestinians areas, meanwhile Palestinians children, they are fighting hard to go to school and to get his right of learning like other children in the world, the Palestinian child, his mentality of thinking is totally different from other children in the world, so nowadays the Palestinian people spread out in the world and they proved how scientifically strong in learning and teaching and in giving important ways to get knowledge and gorgeous experience.

Palestinian Children are fighting for getting their right of learning first and are fighting to improve their country by using their mentalities in creating new education methods to make the next generations have 
the ability and skill to create their own philosophy of learning and teaching and to run the education process and procedures at schools in Palestine effectively and correctly, so it doesn't matter what is the upcoming consequences, because always there is a desire and well to think and to learn more and more about science and it will not be stoppable.

\section{LITERATURE REVIEW}

Education system is that process of facilitating learning, or the Acquisition of knowledge, skills, values, beliefs, and habits. So, educational methods include storytelling, discussion, teaching, training and directed research. Education can take place in formal or informal settings and any experience that has a formative effect on the way one thinks, feels, acts may be considered educational (Dewey, 1944).

Teaching methods is methods which will be used by teachers systems which based on teacher's beliefs, values and goals that hold in relation to the content and process of teaching and their understanding of the system in which they work and their roles in it. Also, it can be identified such as a method used to create a network of elements or parts different from each other but each one is special in the sense that each performs a unique function for the life and effectiveness of the instructional system of teaching (Contesse, 1998).

The definition of school according to wikipedia means that is an institution designed to provide learning spaces (which are the physical settings for learning environments of all kinds) and learning environment ( which is educational approaches, culturalcontext, or physical setting in which teaching and learning occur, The term is a commonly used as a more definitive alternative to "classroom".

Critical thinking is the propensity and skill to engage in an activity with reflective skepticism (McPeck, 1981). critical thinking and subject specificity. It can be reflective and reasonable thinking that is focused on deciding what to believe (Ennis, 1985). It can be skillful, responsible thinking that facilitates good judgment because it relies upon criteria, self corrrecting and it is sensetive to context (Lipman, 1988).

\section{Purpose of Education}

There is no broad consensus as to what education's chief aim or aims are should be. Some authors stress it's value to the individual, emphasizing it's potential for positively influencing student's personal development, promoting autonomy, forming a cultural Identity or establishing a career or occupation. Other authors emphasizes education's contributions to societal purposes, including good citizenship, shaping students into productive members of society, thereby promoting society's general economic development and preserving cultural values (Curriculum Online, 2009).

What is the Palestinian Education System?

The organizational structure of education in Palestine consists of a twelve year elementary school and secondary school and that last year called ( Tawjhi ) in Palestine. The ministry of education pays a strong attention to support education sector and it allocates high percentage in order to make new schools and to employ new experienced teachers who will improve education process. Then after spending twelve year at school, the time will come to move to the university and to start new different life. In this case the ministry of education trying to adopt new ways and methods to create new system of teaching and that's through.

Sending Palestinians students to different countries in the world in order to get new experiments about educational sector and trying to implement it at Palestine schools and universities and to know the benefits reflection in the reality. Making continuous confrences about education in order to know what is the main gap between education and developed education. Adopting new technological methods in order to make an easy access to understand, to analyze and to create impressive ideas.

Offering a lot of educational training programs in order to improve the skills and abilities of both teachers and students and to have a sufficient understanding about education services (Loghod et.al, 1997). Education in Palestine knows well how to make progress every year to improve schools and universities and that's through:

1. Information is a powerful tool for change. So, educational system does not depend on steady information to make a change. But, it depends on how to collect a lot of information in case that there is something wrong in some education areas and to find a solution for this problem as soon as possible.

2. In Palestine annual testing tells us if there is a progress or not at educational instistutions. So, testing the qualities of both teachers and learners is something important in order to know who is capable to get a good position at the the educational area.

3. Also, annual tests show educators what is working and what area need improvements. So, in Palestine this is something urgent to know, so, the results will decide what kind of things should be adopted and followed by who is responsible to fix something wrong was discovered. (Fronk et.al, 1999).

What is the obstacles that impede the education system in Palestine?

1. Lack of financial support and budgets to back up the education system and that's because of limited financial sources to run educational activities as well as possible.

2. High rates of unemployment in education area, unfortunately many students get graduated every year from different universities in Palestine, but it is not easy to find a job as quick as possible and that's because poor economic condition.

3. Higher studies in Palestine are so expensive, so not all students can continue to get more academic certificates and that's because Palestinian economic is controlled by occupation.

4. Complicated access into schools and universities. Sometimes during going to schools every day 
morning, Palestinian children face a lot of challenges such as occupation checkpoints, preventing them from going to get the right of education and depriving them and arresting teachers and students for many years.

5. Importing educational tools to improve the quality of education services is a little bit difficult and that's because a lot of restrictions standing behind that such as expensive payments should be paid during buying it and high taxes rates should be added. Hard access because of occupation (Barakat, 2007).

\section{The Branches of Education Process in Palestine}

In Palestine the education process deploys to have a lot of different life sides not only education system at schools and universities but education in Palestine gives many ideas and information to deal with other sectors and what is the suitable way to get better understanding about it. So, these areas can be sunnarized in those points:

1. Voccational area: focus on giving craftsmanships and developing their abilities in order to make something technical which will lead to serve the society.

2. Agricultural area: focus on providing Palestinians with important techniques to understant the environment in a managed way.

3. Commerce area: focus on how to improve the system of encouraging new investors and to create new projects and how to get a lot of benefits in return to make the economic grows better.

4. Industry area: focus on creating new manufacturing companies that will serve the whole community. And it's important role to reduce the rates of unemployments (Ebeidat and Dhouqan, 2015).

Goals of environmental education in Palestine: (1) to improve the quality of environment; (2) to create an awareness among people on environmental problems and conversations; and (3) to create an atmosphere so that people participate in decision making and develop the capabilities to evaluate the developmental programmes (Loghod et al, 1997).

\section{CONCLUSION}

The conclusions of this article tries to create and extract the most important facts about schools in palestine in order to describe the the Palestinian communities and describe the reality of Palestinian's schools and what is the problems that these schools are still suffering from until today, also, it analyses how the communities can improve the quality of teaching and make the schools one of basic and important location to get knowledge and experiences which will lead to develop the country and it will contribute to overcome any unpredictable cosequences that might lead to impede the process of education in Palestine. So the conclusions can be summarized in such important points such as:

1. All of these schools are effectively keeping students at school and engaged in their learning. They are demonstrating that exciting learning communities can be built over time; communities that provide all students with a sense of belonging, a sense of purpose and the motivation to succeed.

2. All of these schools believe that each of their students can and will succeed, and that it is their job to help them to do so; no matter what challenges may present themselves, there is a way. Staff and students work together to succeed, supported through appropriate resourcing from trustees, strong senior leadership and whānau involvement (Ramzy, 2015).

3. These schools are places of learning for all members of the community: trustees, principals, senior leaders, teachers, parents, whānau, but above all for students. No one aspect makes them succeed, they are a sum of all their parts. Those parts are held together by a strong vision, a vision owned and upheld by the whole community. Each community is built on a foundation of care; respectful and truly caring relationships exist between the members of the school (Hommos, 2013).

4. It takes excellent leadership, extending beyond the principal through to key personnel in the school, to achieve this coherence, to manage change and to maintain the momentum and commitment to continuous improvement. Members of the community are empowered and energised. High relational trust exists in the schools, staffing is stable and the passion for young people and their learning is a tangible characteristic of the schools.

5. These schools have an unswerving focus on each student's learning and hence to improving their outcomes. Students are the heart of the school. Senior leaders in the school make extensive use of the student management system's capabilities to suit their needs. Data, both qualitative and quantitative, is extremely well recorded. Teachers, senior leaders and the board engage with this data, analysing it to identify needs, and to monitor progress and achievements across all levels of the school. Such scrutiny leads to sound self-review processes, informed both by evidence and research, and decisions are made that better tailor programmes and initiatives to meet the needs of individual students and the school.

6. Students in these schools are respected and empowered as learners. They achieve sound academic qualifications and are nurtured with a strong set of values to take into the world beyond school. All of this is achieved despite the fact that so many of their students come from low income families and is clearly against the trends shown for lower decile schools (Faysal, 2003).

Recommendation of this paper in order to make a strong education methods that should be used at schools:

1. Expectations for every student's success are high.

2. Relationships within and beyond the school community are carefully nurtured, respectful and supportive 
3. Evidence and research are used to empower teachers to use and reflect on a range of approaches to effectively engage all students in learning

4. Professional development and interventions are carefully selected and adapted to integrate with the vision and direction of the school.

5. Using the information to identify what approaches and resources are needed to keep every student experiencing success in education (Barakat, 1984).

\section{REFERENCES}

[1] Abello, C. C. 1998. Teaching and Learning Vocabulary: Issues and Perspectives. Great. Revista, 6, 2, 31-37.

[2] Barakat, B. F. 2007. The Struggle for Palestinian National Education Past and Present. In Brock, C., and Levers. L. Z., (Eds). Aspects of Education in the Middle East.

[3] Barakat, H. 1984. Contemporary Arab Society: Social Review. Beirut: Centre for Arab Unity Studies.

[4] Curriculum Online. 2009. Curriculum. Retrieved December 9, 2016, from curriculumonline.gov.uk.

[5] Dewey, J. 1944. Democracy and Education. New York: The Free Press.

[6] Ebeidat, D. 2016. Series of Articles on Education. Alghad: Newspaper Amman.

[7] Faysal, D. 2003. Introduction to Studies of Palestinian Education. Ramallah: Khalil Sakakini Centre and Institute for Palestine Studies.

[8] Fronk, C., Huntington, R. L., and Chadwick, B. A. 1999. Expectations for Traditional Family Roles: Palestinian Adolescents in the West Bank and Gaza.

[9] Frost, D. 2013. Teacher-led Development Work: A Methodology for Building Professional Knowledge. HertsCam Occasional Papers, April, HertsCam Publications, Retrieved December 9, 2016, www.hertscam.org.uk.

[10] Hommos, A. 2013. PA The Day After: Collapse and its Effect on Education. Ramallah: The Palestinian Centre for Policy and Survey Research.

[11] Lipman, M. 1988. Critical Thinking - What can it Be? Educational Leadership, 39.

[12] Loghod, A., Ibrahim, Hammad, and Hussein. 1997. Palestinian Education: History, Reality and Future Needs. Ramallah: Birzeit University.

[13] McPeck, J. E. 1981. Critical Thinking and Subject Specificity. Areply to Ennis Educational Researcher, 8.

[14] Ramzy. R. 2015. Reflections of a Teacher - Rua Educational Magazine. Ramallah: Abdelmoshen Al Qattan Foundation. 